\title{
Fabrication of Humidity Control Ceramics from Drinking-Water Treatment Sludge and Onggi Soil
}

\author{
Min-Jin Lee, Hyeon-Jun Lee, Kyungsun Kim*, and Hae-Jin Hwang ${ }^{\dagger}$ \\ Department of Materials Science and Engineering, Inha University, Incheon 22212, Korea \\ *Division of Pottery, KSP, Incheon 21997, Korea \\ (Received February 19, 2016; Revised February 25, 2016; Accepted February 25, 2016)
}

\begin{abstract}
In this study, humidity control ceramics with good adsorption/desorption capabilities and high strength were fabricated from drinking-water treatment sludge (DWTS) and Onggi soil. The DWTS powder heat-treated at $800^{\circ} \mathrm{C}$ and Onggi soil were mixed at weight ratios of $40: 60,50: 50,60: 40$, and $70: 30$ and fired at $800-1000^{\circ} \mathrm{C}$. With increasing DWTS content, density and flexural strength increased. For the sample with a DWTS:Onggi soil weight ratio of 70:30, porosity and specific surface area decreased with increasing firing temperature, attributed to densification and grain growth at high firing temperatures. From the results obtained, a firing temperature of $800^{\circ} \mathrm{C}$ is the optimum condition for fabricating humidity control ceramics with good adsorption/ desorption capabilities and strength. The maximum adsorbed amount for the sample fired at $800^{\circ} \mathrm{C}$ was $439 \mathrm{~g} / \mathrm{m}^{2}$.
\end{abstract}

Key words : Humidity control ceramics, Adsorption/Desorption capability, Drinking-water treatment sludge (DWTS), Onggi soil, Eco-friendly

\section{Introduction}

I $\mathrm{n}$ residential buildings, humidity control and ventilation are factors critical for human heath as well as for the energy efficiency and durability of buildings. Thus, there is an urgent requirement for developing interior and exterior building finish materials, which can control humidity and ventilation in buildings. A humidity control ceramic is a functional material that controls the humidity of a room by the condensation or evaporation of water, which occurs at a specific humidity level, according to Kelvin's capillary condensation theory. ${ }^{1)}$ As this ceramic contains uniformly sized mesopores, it condenses or liquefies vapor when humidity increases while simultaneously evaporates at low humidity so as to control indoor humidity within a range of $40 \%-70 \%{ }^{2)}$ Besides controlling the indoor humidity, the humidity control ceramic effectively absorbs or eliminates environmentally hazardous material, such as volatile organic compounds (VOCs), which causes sick house syndrome or atopic dermatitis, as well as provides insulation effects; hence, it has attracted attention as an environment-friendly building material that could substitute cement or concrete material. ${ }^{3)}$

On the other hand, the performance of a humidity control ceramic is determined by its water adsorption/desorption capability and rate, and for attaining superior performance,

${ }^{\dagger}$ Corresponding author : Hae-Jin Hwang

E-mail : hjhwang@inha.ac.kr

Tel : +82-32-860-7521 Fax : +82-32-862-4482 it should have uniformly sized mesopores ranging from a few nanometers to $10 \mathrm{~nm}$ and macropores with a size of greater than or equal to $30 \mathrm{~nm}$, which constrain the diffusion of water vapor. ${ }^{4)}$ Typically, lime mortar, humed silica, silica gel, and zeolite cement are known to be humidity control materials; however, these materials exhibit low strength and durability and are not cost-effective. ${ }^{5-8)}$ Recently, super porous minerals with a large specific surface area and meso-sized pores, such as diatomites, volcanic ash, and sepiolite, have attracted attention as humidity control ceramic materials. ${ }^{9-11)}$

Drinking-water treatment sludge (DWTS) is generated by the elimination of impurities from raw water by precipitation, filtration, and chemical treatment at purification plants; it is disposed of by dumping in sea or landfill. Recently, dumping DWTS into the sea has been restricted ever since the London Convention came into effect; moreover, the cost of landfills has been increasingly steadily. DWTS mainly consisting of silica $\left(\mathrm{SiO}_{2}\right)$ and alumina $\left(\mathrm{Al}_{2} \mathrm{O}_{3}\right)$ contains cohesive agents containing $\mathrm{Fe}^{+3}$ or $\mathrm{Al}^{+3}$ and small amounts of organic matter; as compared to sewage sludge, it is less environmentally hazardous, and it is rather similar to clay soil, which is more favorable for recycling into building material. ${ }^{12,13)}$ Onggi soil is a natural mineral, which is used to produce earthenware; it is resistant to acids and alkali, and it exhibits low thermal conductivity and a high insulation effect when fired at appropriate temperatures. Furthermore, it exhibits high fluid tightness and strength as it has very fine pores. Thus, it is called "breathing pottery," with increased utilization. ${ }^{14)}$

In this study, environment-friendly humidity control 
ceramics, which exhibit superior water adsorption and desorption capabilities, were fabricated from DWTS and Onggi soil. DWTS and Onggi soil mixed at different weight ratios were fired at $800-1000^{\circ} \mathrm{C}$. Densification behavior and microstructure were investigated in terms of the firing temperature and the DWTS to Onggi soil weight ratio. The water adsorption and desorption capabilities of the sample were evaluated for determining the applicability as a humidity control ceramic.

\section{Experimental Procedure}

First, DWTS powder was prepared by drying and heattreating dewatered sludge cake, which was supplied from the Incheon Bupyeong drinking water purification plant, at $80^{\circ} \mathrm{C}$ and $700^{\circ} \mathrm{C}$, respectively. Weight loss attributed to the evaporation of water and the decomposition of residual water and organic matter was estimated to be $70 \%-80 \%$ and $35 \%$, respectively. After drying and heat-treatment, the obtained DWTS powder was highly agglomerated; thus, it was pulverized for $12 \mathrm{~h}$ using a planetary mill (Pulverisette 6, Fritsch) using a $2 \mathrm{~mm}$ yttria-stabilized zirconia (YSZ) ball and distilled water.

Onggi soil was purchased from Suksan Ceramics, Korea. As the Onggi soil used herein partly contains large silica particles, it was sieved using a 150 mesh $(\leq 104 \mu \mathrm{m})$. First, the DWTS powder and Onggi soil were mixed using a planetary mill for $12 \mathrm{~h}$. The weight ratios of DWTS:Onggi soil were 40:60, 50:50, 60:40, and 70:30. Second, the powder mixture was fired in an electric furnace at $800-1000^{\circ} \mathrm{C}$. Given the potential damage to the sample by the gas generated during the decomposition of residual organic matter in DWTS powder, the heating rate was limited to $2^{\circ} \mathrm{C} / \mathrm{min}$ for allowing the gas to leak out in the process.

The composition of the DWTS powder and Onggi soil was analyzed by ICP-OES (Optima 5300 DV, Perkin Elmer). The specific surface areas of the dried and fired powder samples were measured by $\mathrm{N}_{2}$ adsorption and desorption (TriStar II 3020, Micromeritics). The powder was pretreated at $350^{\circ} \mathrm{C}$ for $6 \mathrm{~h}$. The density and porosity of the samples were measured by the Archimedes method. The microstructure was monitored by field-emission scanning electron microscopy (FE-SEM, S-4300, Hitachi).

A bar specimen with dimensions of $3 \times 4 \times 40 \mathrm{~mm}$, according to KS (KS L 1591), was fabricated for measuring the flexural strength of the sample. All bar specimens were fractured in the four-point bending mode using a universal testing machine (UTM). The fracture load test was conducted using a jig with an external span of $30 \mathrm{~mm}$ and an internal span of $10 \mathrm{~mm}$. The cross-head speed was $0.5 \mathrm{~mm} /$ min. The flexural strength s was calculated by the following equation.

$$
\sigma=3 \mathrm{P}(\mathrm{L}-\mathrm{l}) / 4 \mathrm{bd} \mathrm{d}^{2}
$$

Here, $\mathrm{P}$ is the fracture load $(\mathrm{N}) ; \mathrm{L}$ and $\mathrm{l}$ are lengths of the outer and inner spans, respectively; $b$ and $d$ are the width and thickness of the sample, respectively.

The adsorption and desorption capabilities of the samples were measured using a thermo-hygrostat (TH-I-180, Jeio Tech). The samples were pretreated at a temperature of $25^{\circ} \mathrm{C}$ and a humidity of $50 \%$ for $24 \mathrm{~h}$. Adsorption by the pretreated sample was conducted at a temperature of $25^{\circ} \mathrm{C}$ and a humidity of $95 \%$ for $12 \mathrm{~h}$, and adsorption capability was evaluated by measuring the weight. For desorption, the sample after the adsorption test was left at a temperature of $25^{\circ} \mathrm{C}$ and a humidity of $30 \%$ for $12 \mathrm{~h}$ before measuring the weight to check the desorption capability. For minimizing error, these adsorption and desorption tests was repeated four times under the same test conditions.

\section{Results and Discussion}

Table 1 summarizes the results obtained from ICP analysis of the DWTS powder and Onggi soil; these materials are mainly composed of $\mathrm{SiO}_{2}, \mathrm{Al}_{2} \mathrm{O}_{3}$, and $\mathrm{Fe}_{2} \mathrm{O}_{3}$. The content of $\mathrm{Al}_{2} \mathrm{O}_{3}$ in DWTS was greater than that in Onggi soil, attributed to aluminates used as a cohesive agent in purification plants. The higher silica content in Onggi soil as compared with that in DWTS is attributed to silica and clay.

Figure 1 shows the TG-DTA curves of DWTS powder and Onggi soil. Exothermic peaks were observed at $100^{\circ} \mathrm{C}$ for both samples, attributed to the evaporation of adsorbed moisture. In Fig. 1(a), large exothermic peaks were observed at $360^{\circ}$ and $580^{\circ} \mathrm{C}$ in DWTS, attributed to the organic matter generated from the purification and decomposition of the cohesive agent, and a modest endothermic peak was observed at $400-500^{\circ} \mathrm{C}$. During heat-treatment, odor was generated from the decomposition of organic matter till $360^{\circ} \mathrm{C}$, which was then eliminated with increasing temperature. Given this fact, the exothermic peak at $360^{\circ} \mathrm{C}$ was attributed to the decomposition of organic matter, while the exothermic peak observed at $580^{\circ} \mathrm{C}$ was attributed to the decomposition of the cohesive agent. In addition, the endothermic peak observed between 400 and $500^{\circ} \mathrm{C}$ was attributed to the evaporation of the water of crystallization from clay minerals in two powders. In Fig. 1 (b), a endothermic peak, as well as significant weight loss, was observed at $410-600^{\circ} \mathrm{C}$, attributed to the generation of metakaolin $\left(\mathrm{Al}_{2}\right.$. $\left.\mathrm{Si}_{2} \mathrm{O}_{7}\right)$ coupled with the dehydration of kaolinite $\left(\mathrm{Al}_{2}\right.$.

Table 1. Chemical Composition of DWTS \& Onggi Soil (\%)

\begin{tabular}{ccccccccccccc}
\hline Materials & $\mathrm{SiO}_{2}$ & $\mathrm{Al}_{2} \mathrm{O}_{3}$ & $\mathrm{Fe}_{2} \mathrm{O}_{3}$ & $\mathrm{TiO}_{2}$ & $\mathrm{CaO}$ & $\mathrm{MgO}$ & $\mathrm{Na}_{2} \mathrm{O}$ & $\mathrm{K}_{2} \mathrm{O}$ & $\mathrm{C}$ & $\mathrm{S}$ & Loss ignition & Water Content \\
\hline DWTS & 48 & 36.2 & 6.35 & 0.58 & 1.1 & 1.36 & 0.7 & 2.1 & 0.1 & 0.02 & 1.87 & 0.67 \\
Onggi soil & 66 & 16.8 & 5.05 & 0.73 & 0.5 & 0.89 & 0.69 & 2.7 & & & 6.73 & \\
\hline
\end{tabular}



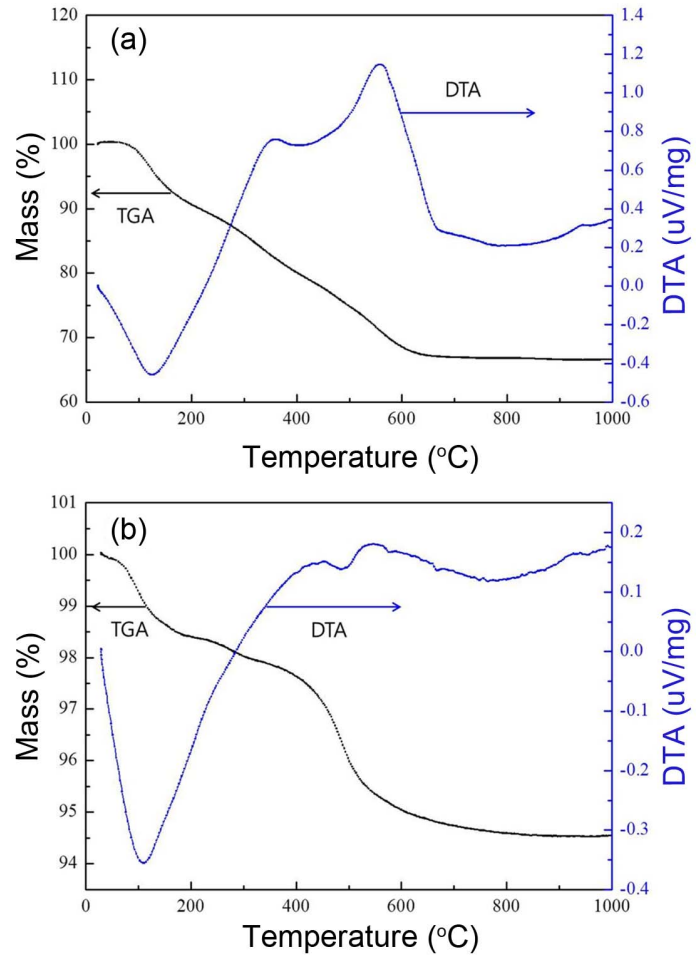

Fig. 1. TG-DTA curves of DWTS (a) \& Onggi soil (b).

\section{$\left.\mathrm{Si}_{2} \mathrm{O}_{5}(\mathrm{OH})_{4}\right)$ in Onggi soil.}

From the results obtained from the TG-DTA analysis of DWTS and Onggi soil, the evaporation of the water of crystallization, decomposition of organic matter, or phase changes were not observed at a temperature of greater than or equal to $800^{\circ} \mathrm{C}$. Given this result, it is imperative to set the firing temperature at a temperature of greater than or equal to $800^{\circ} \mathrm{C}$ for the manufacturing of a humidity control ceramic from DWTS powder and Onggi soil. Moreover, with increasing firing temperature to greater or equal to $1000^{\circ} \mathrm{C}$, pores in DWTS powder and Onggi soil were rapidly eliminated, possibly resulting in the loss of function of the humidity control ceramic. Hence, for fabricating the humidity control ceramic from DWTS powder and Onggi soil, the firing temperature was set at $800-1000^{\circ} \mathrm{C}$.

Figure 2 shows the results obtained from the particle size analysis of DWTS powder and Onggi soil, pulverized for 12 $\mathrm{h}$ after heat treatment at $700^{\circ} \mathrm{C}$. As DWTS is a product obtained from the precipitation or cohesion of a water purification plant, its particle size distribution ranges from a few micrometers to a few tens of micrometers. On the other hand, as compared to DWTS powder, Onggi soil is refined material, with a more fine and narrow grain size distribution, ranging from 3 to $4 \mu \mathrm{m}$.

Figure 3 shows the density, porosity, and bending strength of the sample fired at $985^{\circ} \mathrm{C}$. The weight ratios of DWTS:Onggi soil samples were $40: 60,50: 50,60: 40$, and $70: 30$. As shown in Fig. 3 (a), with increasing DWTS content, density slightly increased, while porosity remained
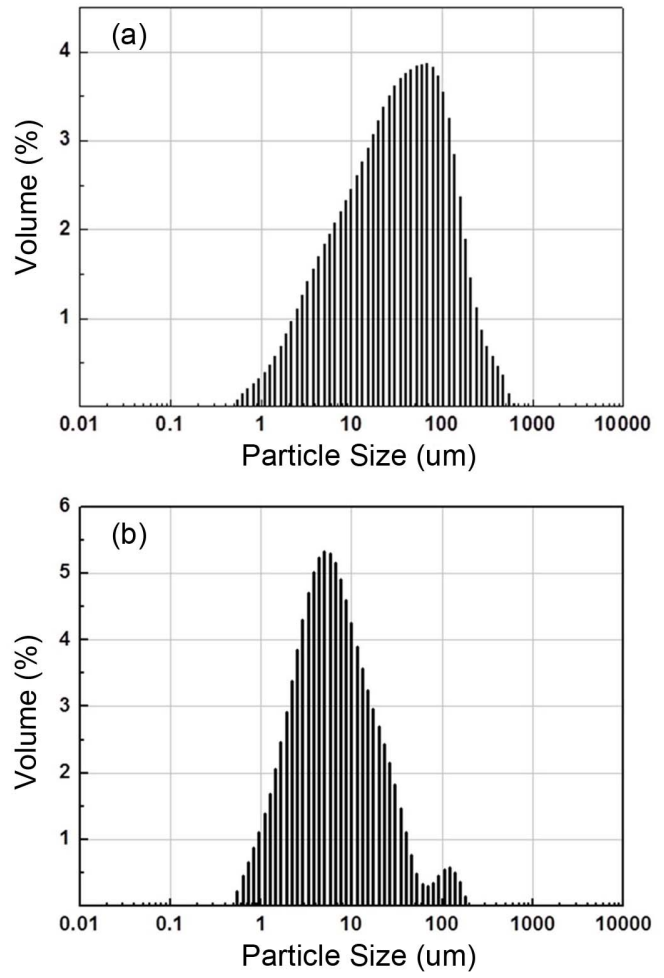

Fig. 2. Particle size distribution of DWTS (a) \& Onggi soil (b).

almost constant. The density and porosity of the sample containing $70 \mathrm{wt} \%$ of DWTS were $1.73 \mathrm{~g} / \mathrm{cm}^{3}$ and $44 \%$, respectively. As compared to Onggi soil, DWTS powder contains more alkali cations, such as $\mathrm{CaO}, \mathrm{Na}_{2} \mathrm{O}$, and $\mathrm{K}_{2} \mathrm{O}$; thus, it tends to form eutectic mixtures, which form liquids at low temperature by reaction with silica and alumina during firing. As a result, with increasing DWTS content, density increases accordingly because of accelerated sintering. ${ }^{15,16)}$ With increasing DWTS content, density also increased, albeit porosity remained constant, rather of drastic reduction, attributed to the residual organic matter present in DWTS, which served as a pore former.

As shown in Fig. 3(b), with increasing DWTS content, bending strength improved. Given that density increases with dependence on DWTS content and that bending strength is sensitive to sample density, the results observed in Fig. 3 (a) and (b) are in agreement. For instance, the density of samples with $40 \%$ and $50 \mathrm{wt} \%$ of DWTS was insignificant, as well the strength remained constant, implying a close relationship between density and strength. Moreover, besides improvement in density, the bending strength of $60 \%$ and $70 \mathrm{wt} \%$ DWTS samples also significantly improved, attributed to another reason. As mentioned before, the eutectic mixture is expected to increase with increasing DWTS content, and for a sample containing a large DWTS content, bending strength is expected to significantly improve because of improvement in necking among the particles.

Table 2 summarizes the density, porosity, and specific 

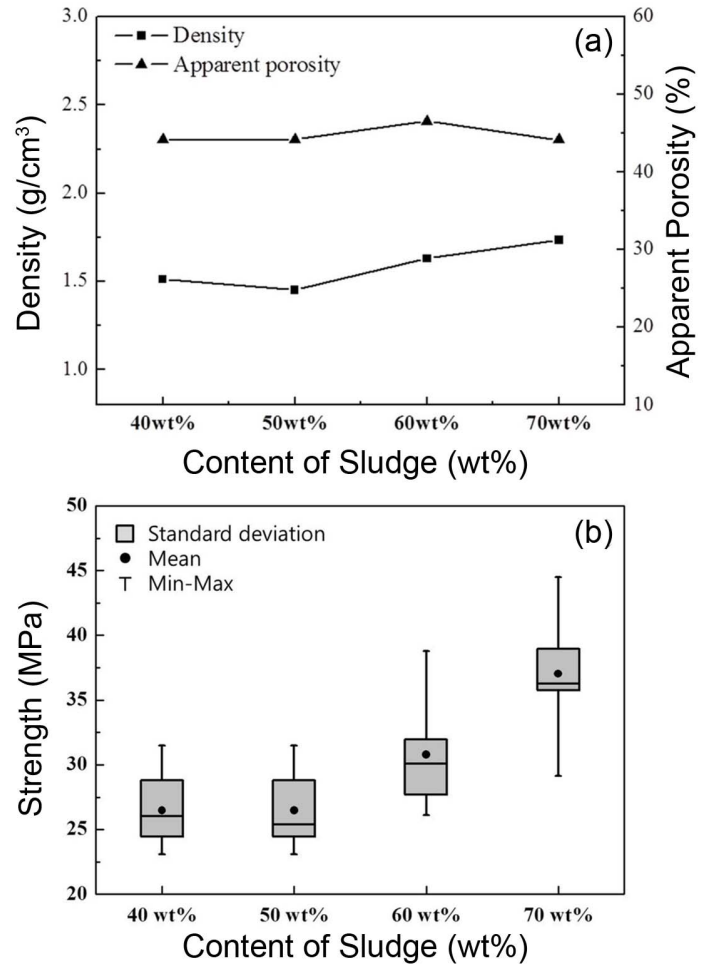

Fig. 3. Density and apparent porosity (a) and flexural strength (b) of the humidity control ceramic sintered at $985^{\circ} \mathrm{C}$.

surface area of samples fired at various temperatures. The ratio of DWTS:Onggi soil was $70: 30$. Density increased with firing temperature, while porosity decreased. Then, the specific surface area significantly decreased with increased firing temperature. For instance, the porosity and specific surface area of the sample fired at $800^{\circ} \mathrm{C}$ was $51.0 \%$ and $42.5 \mathrm{~m}^{2} / \mathrm{g}$, respectively, and porosity decreased to $45.3 \%$ at a firing temperature of $900^{\circ} \mathrm{C}$, although specific surface area decreased to the half or more. Typically, densification gradually progresses with increasing firing temperature, resulting in increased density and grain growth; thus, specific surface area significantly decreases. Particularly, with increasing firing temperature to $800-900^{\circ} \mathrm{C}$, as compared to densification, particle growth increased. Thus, it is necessary to fire samples at temperatures of less than or equal to $900^{\circ} \mathrm{C}$ for producing a sample with superior humidity control performance.

Figure 4 shows the SEM images of the fracture surfaces of

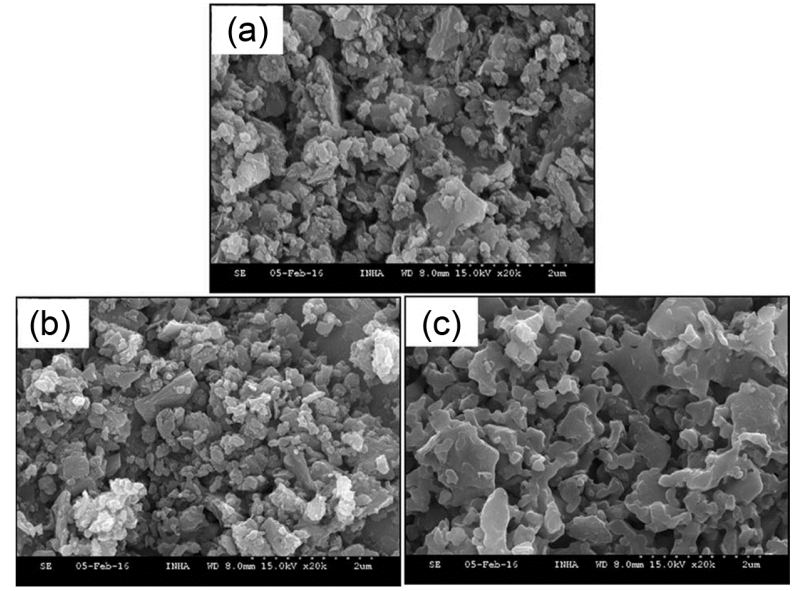

Fig. 4. SEM images of the humidity control ceramic depending on sintering temperature: (a) $800^{\circ} \mathrm{C}$, (b) $900^{\circ} \mathrm{C}$, (c) $985^{\circ} \mathrm{C}$.

the samples fired at 800,900 , and $985^{\circ} \mathrm{C}$ from the sample with a DWTS:Onggi soil weight ratio of $70: 30$. No significant difference in porosity was observed because of the increased firing temperature; however, particle size changed. With increasing firing temperature from 800 to $900^{\circ} \mathrm{C}$, particle size also significantly increased, and in particular, particle growth was considerable, and necking and a dense microstructure were observed in the sample fired at $985^{\circ} \mathrm{C}$. Moreover, with increasing temperature, a network structure consisting of fine particles was formed, and nanosized pores were eliminated first, affording a dense microstructure. As described in Table 2, specific surface area rapidly decreased, which was attributed to densification and particle growth with increasing temperature.

Figure 5 shows the water adsorption and desorption capabilities of the samples fired at $800,850,900,975$, and $985^{\circ} \mathrm{C}$. The weight ratio of DWTS:Onggi soil was $70: 30$. As can be expected from the specific surface areas listed in Table 2, the lower the firing temperature, the higher the adsorption and desorption capabilities, and the capability of the samples fired at temperatures of greater than or equal to $900^{\circ} \mathrm{C}$ significantly decreased, attributed to the elimination of mesopores as well as rapid particle growth caused by firing temperature.

In this study, the fabricated humidity control ceramics exhibited a bending strength of $25.8 \mathrm{MPa}$, a specific surface area of $42.5 \mathrm{~m}^{2} / \mathrm{g}$, and adsorption and desorption capabili-

Table 2. Density, Apparent Porosity, and Specific Surface Area of the Humidity Control Ceramic Manufactured Using a Mixture of DWTS and Onggi Soil Powders at a Weight Ratio of 70:30

\begin{tabular}{ccccc}
\hline $\begin{array}{c}\text { DWTS : Onggi soil } \\
\text { (wt\%) }\end{array}$ & $\begin{array}{c}\text { Firing temperature } \\
\left({ }^{\circ} \mathrm{C}\right)\end{array}$ & $\begin{array}{c}\text { Apparent porosity } \\
(\%)\end{array}$ & $\begin{array}{c}\text { Density } \\
\left(\mathrm{g} / \mathrm{cm}^{3}\right)\end{array}$ & $\begin{array}{c}\text { Specific surface area } \\
\left(\mathrm{m}^{2} / \mathrm{g}\right)\end{array}$ \\
\hline & 800 & 51.0 & 1.28 & 42.5 \\
\multirow{2}{*}{$70: 30$} & 900 & 45.3 & 1.36 & 18 \\
& 975 & 42.9 & 1.50 & 8.5 \\
& 985 & 44.1 & 1.73 & 8.3 \\
\hline
\end{tabular}




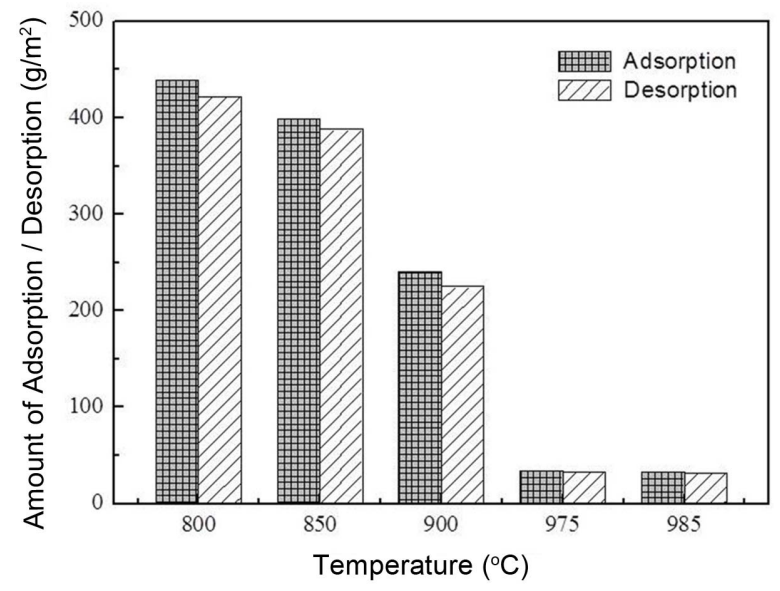

Fig. 5. Amount of adsorption/desorption of the humidity control ceramic depending on sintering temperature.

ties of $439 \mathrm{~g} / \mathrm{m}^{2}$ and $422 \mathrm{~g} / \mathrm{m}^{2}$, respectively, while the bending strength, specific surface area, and adsorption and desorption capability of a commercially available humidity control tile were $22.9 \mathrm{MPa}, 37.4 \mathrm{~m}^{2} / \mathrm{g}$, and $400 \mathrm{~g} / \mathrm{m}^{2}$, respectively. ${ }^{17)}$ Hence, DWTS and Onggi soil demonstrate superior performance and can be employed as humidity control ceramic materials.

\section{Conclusions}

In this study, an humidity control ceramic with superior adsorption and desorption capabilities was produced using DWTS and Onggi soil. Although the density slightly increased with increasing DWTS content, porosity decrease was insignificant, while specific surface area increased, indicating that the performance of humidity control ceramic increases with increasing DWTS content. For the sample with a DWTS : Onggi soil weight ratio of $70: 30$, porosity and specific surface area decreased with increasing firing temperature, as well as adsorption/desorption capability. At a firing temperature of greater than or equal to $900^{\circ} \mathrm{C}$, the porosity decrease for the samples was insignificant, although specific surface area and adsorption/desorption capability significantly decreased because of rapid particle growth. The specific surface area and adsorption/desorption capability of the sample with a DWTS:Onggi soil weight ratio of $70: 30$ fired at $800^{\circ} \mathrm{C}$ were $42.5 \mathrm{~m}^{2} / \mathrm{g}$ and $439 \mathrm{~g} / \mathrm{m}^{2}$ and $422 \mathrm{~g} / \mathrm{m}^{2}$, respectively, demonstrating superior adsorption and desorption performance.

\section{REFERENCES}

1. S. J. Gregg and K. S. W. Sing, Adsorption Surface Area and Porosity; Vol. 3, pp. 111-91, Academic Press, London, 1982.

2. M. Maddison, T. Mauring, K. Kirsimäe, and Ù'. Mander, "The Humidity Buffer Capacity of Clay-Sand Plaster Filled with Phytomass from Treatment Wetlands," Build. Environ., 44 1864-68 (2009).

3. E. J. Jeong, J. K. Lee, D. S. Cheong, Y. S. Chu, and H. Song, "Hygroscopic Characteristic of Gypsum Boards Using Porous Materials," Kor. J. Mater. Res., 19 [10] 538-43 (2009).

4. I. H. Song, E. J. Lee, H.D. Kim, Y. W. Kim, and D. W. Yun, "Investigation on the Peoperties of a Microcellular LightWeighted Humidity Controlling Tile," J. Korean Ceram. Soc., 48 [5] 404-11 (2011).

5. A. E. Turki, R. J. Ball, S. Holmes, W. J. Allen, and G. C. Allen, "Environmental Cycling and Laboratory Testing to Evaluate the Significance of Moisture Control for Lime Mortars," Construct. Build. Mater., 24 1392-97 (2010).

6. F. Ohashi, M. Maeda, K. Inukai, M. Suzuki, and S. Tomura, "Study on Intelligent Humidity Control Materials: Water Vapor Adsorption Properties of Mesostructured Silica Derived from Amorphous Fumed Silica," J. Mater. Sci., 34 [6] 1341-46 (1999).

7. K. Goto and S. Terao, "Structures and Humidity Controlling Performances of Zeolite-Cement Hardened Body," J. Ceram. Soc. Jpn., 113 [11] 736-42 (2005).

8. Y. Tomita, R. Takahashi, S. Sato, T. Sodesawa, and M. Otsuda, "Humidity Control Ability of Silica with Bimodal Pore Structures Prepared from Water Glass," J. Ceram. Soc. Jpn., 112 [9] 491-95 (2004)

9. D. H. Vu, K. S. Wang, and B. H. Bac, "Humidity Control Porous Ceramics Prepared from Waste and Porous Materials," Mater. Lett., 65 940-43 (2011).

10. Y. Jia, W. Han, G. Xiong, and W. Yang, "Diatomite as High Performance and Environmental Friendly Catalysts for Phenol Hydroxylation with $\mathrm{H}_{2} \mathrm{O}_{2}$, Sci. Technol. Adv. Mater., 8 [1-2] 106-9 (2007).

11. J. C. Gonzalez, M. M. Sabio, and F. R. Reinoso, "SepioliteBased Adsorbents as Humidity Controller," Appl. Clay. Sci., 20 [3] 111-18 (2001).

12. A. O. Babatunde and Y. Q. Zhao, "Constructive Approaches toward Water Treatment Works Sludge Management: An International Review of Beneficial Reuses," Crit. Rev. Environ. Sci. Technol., 37 129-64 (2007).

13. M. Razali, Y. Q. Zhao, and M. Bruen, "Effectiveness of a Drinking-Water Treatment Sludge in Removing Different Phosphorus Species from Aqueous Solution," Sep. Purif. Technol., 55 [3] 300-6 (2007).

14. G. H. Seo, B. S. Song, D. S. An, S. K. Chung, and D. S. Lee, "Physical Properties of Korean Earthenware(Onggi) as Food Container," Packag. Technol. Sci., 19 [5] 269-78 (2006)

15. K. Kim, Y. Kim, and S. Kim, "Development of s Sinter-Aids Using a Recycled Glass Powders for Sintering of Clay Brick at a Low-temperature," Journal of Industrial Science and Technology Institute, 26 [1] 59-66 (2012).

16. C. M. F. Vieira, R. Sanchez, S. N. Monteiro, N. Lalla, and N. Quaranta, "Recycling of Electric Arc Furnace Dust into Red Ceramic," J. Mater. Res. Technol., 2 [2] 88-92 (2013)

17. Lixil company, http://www.lixil.co.jp/lineup/tile/ecocarat/. Accessed on 02/23/2016. 